\title{
Experience of Social Interaction of a Future Specialist as a Unified Basis for Continuous Education
}

\section{Experiencia de interacción social de un futuro especialista como base unificada para la educación continua}

\author{
I.V. Gubarenkow*
}

Belgorod State Institute of Arts and Culture, Belgorod, Russia ORCID: https://orcid.org/0000-0002-8067-7956

\section{V.I. Kovalenko}

Belgorod State Institute of Arts and Culture, Belgorod, Russia ORCID: https://orcid.org/0000-0003-4492-2229

\section{E.V. Kolensnikov}

I.D. Putilin Belgorod Institute of Law, Ministry of Internal Affairs of Russia, Russia ORCID: https://orcid.org/0000-0003-0293-7457

\section{O.A. Sokolova}

Belgorod State Institute of Arts and Culture, Belgorod, Russia ORCID: https://orcid.org/0000-0002-2624-5976

*Correspondence

Email: ira.gubarenko@yandex.ru
Cite as:

\footnotetext{
Gubarenko, I.V., Kovalenko, V.I., Kolensnikov, E.V., \& Sokolova, O.A. (2020). Experience of Social Interaction of a Future Specialist as a Unified Basis for Continuous Education. Propósitos y Representaciones, 8 (SPE2), e651. Doi: http://dx.doi.org/10.20511/pyr2020.v8nSPE2.651
} 


\section{Summary}

The implementation of the competency-based approach in a multi-level education system has posed the problem of continuity of its levels. The search for common grounds in choosing the content and results of education has intensified. The scientific interest in the student's experience has grown, as the basic basis for the formation of competencies. Experience is an extremely general category in the scientific apparatus of many sciences, such as philosophy, sociology, psychology, pedagogy, and understanding of its essential properties determines the choice of the content of education. Increasingly, the experience of human behavior in a changing society is becoming the subject of research by educators. Educational standards for training specialists in the sociogenic sphere contain a capacious block of social competencies formed in the educational process at the meta-subject and subject levels. The difficulty of ensuring the systemic integrity of the content of education, which includes individual, disparate elements of activity reflected in the social competencies of a future specialist, determines the theoretical and experimental search for an effective educational construct that maximally covers the content of these competencies and the ways of its formation. The genesis of the concept of social interaction indicates the progressive movement of scientific ideas from a socially insignificant and little studied phenomenon to its dominant role in the formation and development of social reality. In most psychological and pedagogical concepts, experience is considered as a passive result of activity, which determines its static structure. The dynamic structure of the experience of social interaction is formed by the value-semantic, thought-activity and expressive-activity components. Subjectivity, co-existence, and reflexivity are proposed as the through lines of its enrichment for all levels of education. The results of the study can serve as a theoretical basis for designing the enrichment of the experience of social interaction of students at different levels of education.

Keywords: Experience; Social Interaction; Foundation of Continuity; Levels of Education.

\section{Resumen}

La implementación del enfoque basado en competencias en un sistema educativo multinivel tiene el problema de la continuidad de sus niveles. La búsqueda de un terreno común para elegir el contenido y los resultados de la educación se ha intensificado. El interés científico en la experiencia del alumno ha crecido como base básica para la formación de competencias. La experiencia es una categoría extremadamente general en el aparato científico de muchas ciencias, como la filosofía, la sociología, la psicología, la pedagogía y la comprensión de sus propiedades esenciales que determinan la elección del contenido educativo. Cada vez más, la experiencia del comportamiento humano en una sociedad cambiante se está convirtiendo en objeto de investigación por parte de los educadores. Las normas educativas para la formación de especialistas en el campo sociogénico contienen un bloque de capacidades sociales formadas en el proceso educativo a nivel meta-sujeto y sujeto. La dificultad de garantizar la integridad sistemática del contenido educativo, que incluye elementos individuales y dispares de actividad reflejados en las competencias sociales de un futuro especialista, determina la búsqueda teórica y experimental de una construcción educativa efectiva que cubra al máximo el contenido de estas competencias. y las formas de su formación. La génesis del concepto de interacción social indica el movimiento progresivo de ideas científicas de un fenómeno socialmente insignificante y poco estudiado a su papel dominante en la formación y desarrollo de la realidad social. En la mayoría de los conceptos psicológicos y pedagógicos, la experiencia se considera un resultado pasivo de la actividad, que determina su estructura estática. La estructura dinámica de la experiencia de interacción social está formada por los componentes de valor semántico, actividad de pensamiento y actividad expresiva. La subjetividad, la coexistencia y la reflexividad se proponen como líneas de enriquecimiento para todos los niveles de la educación. Los resultados del estudio pueden servir como base teórica para diseñar el enriquecimiento de la experiencia de interacción social de los estudiantes en diferentes niveles de educación. 
Palabras clave: Experiencia; Interacción social; Fundamento de Continuidad; Niveles de Educación.

\section{Introduction}

The appeal to the experience of social interaction of students as a common basis for the continuity of all levels of education is due to the increasing role of the ways of interaction of individual, group and institutional subjects of society in its safety and development. In the implementation of competency-based educational standards, teachers actively seek a holistic foundation for the formation of a variety of social and professional competencies. As such a basis, we consider the experience of social interaction of students, which is formed throughout life, including in pedagogical interaction.

In December 2001, the Government of the Russian Federation considered and approved the Concept of Modernisation of Russian Education for the Period up to 2010 [1] developed by the Ministry of Education of Russia. The document states that the governmental, political, social and economic transformations of the late 1980s and the early 1990s made an essential impact on Russian education and, in particular, allowed the development of the non-governmental sector of education. The measures on modernisation of Russian education were suggested to include further development of non-governmental educational organisations/establishments with a simultaneous increase in control over the quality of educational programs they implement. In particular, an increase in the requirement of quality vocational training, re-attestation and repeated licensing of non-governmental institutes of higher education issuing state-approved diplomas as appropriate. Seven years passed, and in December 2008, the Minister of Education and Science A. Fursenko had to recognise the expediency of an essential reduction in the total number of institutes of higher education operating in the country. The minister stated that Russia today has about 50 serious competitive universities. Some 150-200 more institutes of higher education provide good education, but with narrower specialisations. All in all, there are 1,500 accredited institutes of higher education and 2,200 branches in the country today. According to A. Fursenko, "in the near future, the number of branches of institutes of higher education in the regions will halve, some of them being closed, others being attached to those providing better education. In about four years, the number of institutes of higher education is going to be cut by $20 \%$, also by reorganisation and through mergers" [2]. It is reasonable to expect that the modernisation of the Russian system of higher education will affect non-governmental institutes of higher education first of all. Practice shows that a lot of non-governmental institutes of higher education in Russia do not provide the necessary quality of training for students for the following reasons: (a) their training and methodological basis is weak. As a rule, they have insufficiently well-equipped educational premises, out-of-date hardware, labware and research literature; 27 (b) the regular faculty is scanty. The primary academic load is fulfilled by hourly workers, highly qualified teachers of many subjects being unavailable; (c) the methodological maintenance of the academic process is primitive. As little original authoring as there is, there is no financial stimulus for it to be introduced; (d) at the stage of enrolment of students, there is no strict selection of entrants. Nongovernmental institutes of higher education actually take in all solvent "customers"; (e) the widely advertised individual approach to teaching actually turns into low exactitude with students. Although there is some fall-off as a result of attestation, it is insignificant; (f) teachers and students carry out no serious research work as there is no necessary funding; (g) the overwhelming majority of non-governmental institutes of higher education have no internal system of control over the quality of training, and the students are deprived of a real ability to influence the quality of the educational process; (h) the heads of the non-governmental institutes of higher education include a lot of come-and-go people, ignoring democratic principles of university education. Regular teachers have no reliable protection against their arbitrariness. The today's licensing of educational activity does not guarantee quality of education: according to Article 33.9 of the law On Education, "the content, organisation and methods of the educational process shall not be the 
subject of expert examination" [3]. According to the established order, the institute of higher education to be attested shall itself draw up a report on its achievements in the accounting period. This document is quite often made up in such a way that truth intertwines with fiction in a hope that the officials checking the institute of higher education and representatives of governmental institutes of higher education will not get to the fact of the matter. As a rule, the committee is met in a very hospitable way as generous payment for consultations held by the members of the committees removes many questions; the self-authored report of the institute of higher education is amended as appropriate, and the expert judgement with a positive assessment is usually subscribed to unanimously. Certainly, it is not everywhere and not always that everything goes off so smoothly. If the non-governmental institute of higher education gets on a "black list" with the Ministry of Education and Science of the Russian Federation, the reason being litigation between an institute of 28 higher education and a student's parent, the institute of higher education is usually in for serious complications at the stage of governmental attestation. As for the general tendency, it is as follows: despite its apparent defects, the non-governmental sector of higher education goes on developing extensively, seizing increasingly more territories in the regions. In a situation where licences are extremely seldomly withdrawn, and nobody is going to close unaccredited institutes of higher education, the non-governmental sector of higher education is becoming stronger, gaining vigour and establishing the necessary contacts with the authorities it needs. Non-governmental institutes of higher education have enough funds to attain their goals, which allows successful lobbying for their interests at various levels. To change this situation, the Ministry of Education and Science of the Russian Federation is going to finish development of the draft law on education in the near future and submit it to the general public for discussion. You can find our own proposals as applied to higher education below. In our opinion, it is high time we changed the existing order of licensing of university activities. The respective requirements should contain some absolutely unambiguous obligations of the educational institution on the necessary quality of the educational process. Every institute of higher education should clearly understand what is meant by qualitative training of students, which the institute of higher education must guarantee from the very beginning of its activity and not only in the long term. At the same time, we think we should introduce a new procedure of compliance testing with the licence requirements at the stages of governmental attestation. The necessary information should be assembled regularly - say, annually - and from various sources, which is very important. In addition to the respective committees of the Ministry of Education and Science of the Russian Federation, the quality of training should also be assessed by the organisations concerned - first of all, business structures and public organisations of students. The normal functioning and development of a modern institute of higher education is known to need considerable capital. That means that institutes of higher education have to be founded by well-off physical and legal bodies, who can be subdivided into two groups. One group is comprised of those who invest material resources, including funds, into the institute of higher education. This group of founders can be represented by: 29 (a) the governmental bodies or organisations placing educational and other premises at the disposal of the institute of higher education on some terms; (b) entrepreneurial structures represented by particular firms investing some funds into the educational facilities and the resource base of the institute of higher education, e.g. creation of a library, laboratories, computer classes, etc.; (c) public organisations representing the students and other consumers of educational services paying for their training. Another group of founders is made up of direct organisers and participants of the educational activity, including: (a) the institutes of higher education attested and accredited by the government and able to actively contribute to methodological support of the educational process in a new institute of higher education; (b) highly skilled faculty ready to work in a new institute of higher education on a regular basis; (c) managers experienced in organizing educational activity. In the above system of co-foundation, it is necessary to identify and legislatively fix the primary, leading link possessing the necessary authorities to be licensed for educational activity. In our opinion, such a founder should be represented by highly skilled faculty ready to work in the institute of higher education on a regular basis. Practical experience has convincingly shown that: The majority of today's Russian establishments of education have no steady connection with employers, the markets of labour and education being actually independently from each other. As a result, a lot of enterprises are short 
of qualified workers and specialists, and a considerable number of graduates of higher educational institutions have to work in careers for which they are not trained. It seems necessary to legally fix not only the right but also the obligation of business to take part in professional training of employees. For this purpose, the following measures seem expedient to take: 1) to create a national system of professional standards as the basis of governmental educational standards, which would become a system of independent assessment of the quality of education and certification of qualifications; 2) to form databases aimed at the objective assessment of the labour market and forecast the demand in workers and specialists in the long run. It also seems expedient to amend tax laws to allow payment for not only direct training costs, but also adjacent costs, including investments into the resource base of educational institutions, retraining of personnel, etc., 30 as corporate educational costs. According to a recently adopted law, today's higher educational institutions are entitled to found small innovative enterprises on a commission basis. That means that Russian institutes of higher education can now more fully implement their intellectual potential, but only if business structures provide them with respective orders

\section{Materials and methods}

In educational practice, a significant contradiction is aggravated between the social need to prepare students for productive, open, creative interaction in society based on the necessary experience formed in the educational process, on the one hand, and the teacher's unpreparedness to ensure this social need due to the lack of theoretical and methodological foundations for this process. This contradiction forms the research problem: "What are the theoretical and methodological foundations for enriching the experience of social interaction of students at all levels of higher education?"

Turning to the experience of social interaction as the content of education requires determining the essential characteristics, structure, functions, criteria, and indicators of its diagnosis. An equally difficult research task was to develop a methodology for enriching the experience of social interaction of students in the academic educational process.

Scientific sources were studied that made it possible to trace the genesis of the concepts of "experience of social interaction" and "enrichment of experience", the essential characteristics and the role of these psychological and pedagogical phenomena in the training and professional activities of future humanitarian specialists. Theoretical methods of analysis, synthesis, abstraction, systematization, modeling was used.

\section{Methodological approaches}

The methodological basis of the study was the ideas and principles of the system, activity, competence, and personality approaches, presenting the subject of research in all its multifacetedness, multidimensionality, and systemic integrity. Such a polyparadigm approach allowed us to consider the experience of social interaction of the student in its system coordinates of activity, personality, and consciousness.

\section{The genesis of the concept of "social interaction"}

The categories "experience" and "social interaction" are universal, extremely general categories and, at the same time, philosophical, sociological, psychological, and pedagogical phenomena. Appeal thereto in the context of studying the pedagogical process of preparing future specialists for life in society is due to the increasing importance of the way social systems interact in a changing and becoming complicated world. 
We should note that the study of the category of "social interaction", the fundamental science of man and society, still does not have clear and unambiguous options for a scientifically based concept.

The process of formation of the theory of social interaction was complex, lengthy, and controversial. Its first developers were philosophers and sociologists. For the first time, the ideas of social interaction found theoretical and methodological substantiation in the works by classics of philosophy and sociology of the XIX century and the first half of the XX century.

A. Comte considers social interaction as a basic element of social structure in the context of intra-family relations and the establishment of relationships through personal interests within the family (Comte, 1971).

E. Durkheim defines the essence of social interaction through relationships that attract people to each other (Durkheim, 1996). G. Simmel sees it as mutual influences on each other (Simmel, 1996).

P.A. Sorokin brings into the theory of social interaction its additional essential feature its global process nature (Sorokin, 2008).

The second half of the XX century made significant adjustments to scientific ideas about social interaction, supplementing and expanding them. The attention of scientists is attracted by important changes in public life. Along with objective reality, subjective factors of social change are no less important. In new views on social interaction, the objective social reality and the individual uniqueness of the motives and needs of participants in interactions become complementary elements of analysis.

J. Mead, the founder of the school of symbolic interactionism, attaches greater importance to the influence of human on social reality, considering social interaction from the standpoint of communication in an adequate system of symbols that provides a uniform understanding of the content of symbols by people (Mead, 1996).

The representative of the school of structural functionalism - T. Parsons, on the basis of correlation of interaction and social system, concludes that social systems are the result of longterm interactions (Parsons, 2018). Conformists R. Darendorf and L.A. Coser come to the same conclusions, defining social interaction based on conflicts that determine the development of social systems (Darendorf, 1965; Coser, 200).

D. Homans, the founder of the school of the theory of exchange, made a further contribution to the theory of social interaction, proposing the concept of a rational beginning of social behavior of a person driven by prudent motives and a continuous pursuit of profit, achievement of material and financial well-being, satisfaction of social needs for help, approval, love, friendship, and luck (Homans, 1961).

The concept of I. Hoffmann significantly developed the theory of social interaction, based on the analysis of routine social interaction, representing a certain theatrical performance of its participants, seeking to create other people's desired impressions based on the creation of artificial staged situations (Hoffman, 2004).

A special place in the history of knowledge of social interaction belongs to the phenomenological model of A. Schütz, which reflects the pattern of interaction formation under the influence of previously established stereotypes of behavior - a product of the past experience of its participants. The author examines the phenomenon of social interaction in the context of the types of previous social experience of a person and the meanings attached to them by situations of social interaction (A. Schütz, 2003). His followers - P. Berger and T. Luckman, developing 
this concept, convincingly prove the vital necessity of interaction and communication for a person as sources of the formation of his social essence (Berger \& Luckman, 1995).

The genesis of the concept of social interaction indicates the progressive movement of scientific ideas from a socially insignificant and little studied phenomenon to its dominant role in the formation and development of social reality. "Social interactions are the basis, the essence of social reality, in relation to which other social structures, institutions are considered as secondary" (Sergeeva, p. 36).

\section{The concept and structure of the experience of social interaction}

Philosophy often uses "experience" to holistically and universally define knowledge, skills, feelings, and will, generated during sensory reflection of the external world in the process of interaction with it and as a result of this interaction. In psychology, the experience of the individual acts as its most important structural component, which ensures its development, on the one hand, and, on the other hand, as a specific invariant regulator of human life in a changing world.

According to E.V. Kovalenko, the experience of social interaction is a mental trail of a person's practice in society and performs a meta-subject function in his life (Kovalenko, 2018, p. 36). This view was methodologically important for determining the structural components of the experience of social interaction of a future specialist.

The determination of the psychic trail of the variety of real-life situations of social interaction experienced by a person requires bringing them to a common basis - the allocation of the psychic form of the result of interaction and the content of the joint activity of social subjects. Such structural universalization of situations of social interaction is possible provided that social interaction is considered as a separate type of activity, namely, joint activity, more sophisticated than individual activity.

To determine the structure of experience, it is important to determine the concept and basic subsystems of personality. Te study relied on the concept of personality by D.A. Lentiev, concentratedly presented by him in the book "Essay on the Psychology of Personality". The author considers the property of "personality" as "a person's ability to act as an autonomous carrier of universal human experience and the forms of behavior and activity historically developed by mankind", distinguishing three hierarchical levels in a person that have conditional boundaries: the level of nuclear structures, the level of individual's relationship with the world, and the level of expressive instrumental structures "(Leontyev, 1993, p. 8). The experience of the social interaction of the individual, reflecting the activity-active part of the mastered social experience, forms these level substructures in the corresponding mental forms.

S.V. Istomina (2015), considering experience as a dynamic information system of the external and internal world of a person that determines the strategy and success of an activity, singles out personal meaning as its core - an integral element of the motivational sphere. M.A. Kholodnaia (2002) defines the essence of mental experience through the ability to perceive, interpret and evaluate reality on the basis of a system of personality constructs. The developers of the subject-activity approach, exploring experience, focus on the personal coordinate system where the person perceives and evaluates the social situation, thereby emphasizing the importance of the value-semantic, worldview element.

A.K. Osnitskii, introducing the concept of "regulatory experience" into scientific use, defines it as systemically organized knowledge, skills and experiences and identifies five of its 
types: value experience; experience of reflection; experience of habitual activation; operational experience; and experience of cooperation (Osnitskii, 2000; Osnitskii, 2017).

M. Weber introduced into scientific use the concept of "social action", "which, according to the meaning assumed by the actor or actors, is correlated with the action of other people and is oriented towards it" (Weber, 1990). Social actions, as relatively completed separate acts of interactions, are determined both by the properties of the social systems they are carried out in, and by the individual characteristics of the subjects. Taking as the basis of classification the reactivity and meaningfulness of social actions performed by a person, M. Weber gives their typology, singling out affective (reckless, based on feelings and emotions), traditional (stereotypical, according to a single model in established, repetitive conditions), value-rational (meaningful, but not focused on the goal of the activity, but on values), and goal-oriented (conscious, algorithmized in accordance with the plan to achieve the goal) actions.

The above essential features of the experience of social interaction of a personality allowed us to determine its structure: a value-semantic component, a thought-activity component, and an expressive-activity component. The next task of the study was to find the basis for continuity for all levels of competency-based education systems.

\section{The through lines of enrichment of the experience of social interaction of students at all levels of education}

The competency-based approach implemented in the modern pan-European educational space involves the organization of the educational process in terms of the expected educational result, expressed in the form of competencies. Russian pedagogical science has no unambiguous understanding of similar, but not identical constructs of the competency-based approach of "competency" and "competence". I.A. Zimniaia considers competence as a hidden psychological neoplasm, and competency - as an actual quality of personality, a peculiar manifestation of competence (Zimnaya, 2004).

The basis of competences is the experience of performing activities, represented by subject and procedural knowledge, the ability to apply this knowledge in a specific subject activity, as well as the ability to use methods for solving problems and tasks.

A.M. Novikov reveals the essence of the concept of "education" as "the development of a person's life experience, building his own image of the world and finding his place in it" (Novikov, 2010, p. 12).

P. McLaren, a supporter of critical pedagogy, believes that "the activities of university teachers are ideological in nature", "... they should have a clue of how the experience of students is refracted through the prism of their knowledge, ideas, views, attitudes" (Maclaren, 2016). Experience is the main element of personality development, the bearer of the result of socialization and individualization of a person in society, at the same time fulfilling the role of a protective element from its negative effects on the person. This function of experience can be called the function of social homeostasis of the individual, ensuring its stable position in the system of social relations and connections.

Experience is the basis for the formation of various competences in the process of training and education of schoolchildren and students, which has recently led to an increase in the interest of psychologists and teachers in this phenomenon. Insufficient attention is paid to experience in professional education, limited to its division into two types: personal and professional experience. M.Iu. Plotnikova defines professional experience as "a systematic education that includes substantial, operational, and personal components characterized by uniqueness, awareness, self-worth, productivity and willingness to solve the problems of professional activity" (Plotnikova, 2008). 
Most researchers of professional experience proceed from the structure of experience as a whole: the operational component (professional skills), the substantive component (knowledge and perceptions), and the personal component (relationships). Such a static structure of experience does not provide a systematic idea of the dynamic processes occurring in this formation in the real life of the subject. Experience turns out to be involved in all its conscious and unconscious acts and actions, performing the functions of a basic resource and an evaluation standard of activity.

The concept by A.K. Osnitskii reflects the dynamic nature of experience, which, in his opinion, represents "a certain structured system of knowledge, skills, experiences that make up a person's idea of professional self-determination and ensure the success of the regulation of his activities and behavior" (Osnitskii, 2000). In the regulatory level of experience, the author identifies the value, reflective, operational components, as well as the cooperation that develops during interaction and the usual way of activation.

In our opinion, the experience of social interaction, being the basic component of a person's social experience, is isomorphic in its structure to personality and activity, and in terms of awareness corresponds to levels of consciousness. The placement of experience in the "activitypersonality-consciousness" coordinates allows exploring it as an integral system of actual mental reflection of previous activities and interactions, whose participant is the person. Such a structurally-dynamic (systemic) approach makes it possible to model and shape experience based on the integration of elements of activity and personality. This raises the problem of correlation of the forms of these elements.

The educational process represents the activity by the knowledge, skills and abilities necessary for its successful implementation, and the personality by the qualities that ensure this process. As a general rule, the first, operational group of the educational result is formed in training, and the second, personal - in education. This rather conditional division in educational practice has a real embodiment in that the corresponding structural divisions of educational organizations carry out these processes separately, teachers and lecturers teach, educational departments and services educate.

This contradiction should be settled not through the distinguishing features of these elements of the educational result, but through their general basis. This basis is a way, as an elementary unit of activity. At the same time, the method is also an elementary unit of the process of evaluating a person and his activity, the result of which is the quality attributed thereto by the evaluating subject. A separate personality quality is nothing more than a peculiar sign (label) assigned to it on the basis of the prevailing method of corresponding behavior, activity. E. Fromm singled out two ways of human life: "to be" and "have", which conditionally divide all people into two groups of "creators" and "consumers" (Fromm, 2015). Similarly, the division into "good" and "evil", "courage" and "cowardly", etc. occurs. The basis of the quality of studies that dominates education is the binary nature of the estimated coordinates, at one pole of which there is a way of behavior and activity that is desired by a particular community (+), and not of the desired way (-) at the other. In real life, a person shows his characteristic binary, duality in specific situations, "fits" in the range of evaluation poles. From these positions, the educational process acquires the objectivity of the tasks of training and education, as opposed to the declarative nature of the goals of educational work in higher education.

The experience of human social interaction most vividly displays a dynamic essence in comparison with its other types. J. Kelly, considering the cognitive aspect of experience, defines it as "a person's ability to perceive, interpret and evaluate reality on the basis of a certain way of organized system of personality constructs" (Kelly, 2000). 
Teaching standard and non-standard ways of thinking, a variety of cognitive and behavioral strategies, methods of self-regulation and joint regulation of interrelated activities, help in building own system of life and professional coordinates, solving the pedagogical task of enriching social experience, is at the same time a substantive and procedural basis for educating the student.

The problem of choosing the basis for the continuity of different levels of education is relevant for multilevel education. Considering as such the experience of the student's social interaction, which development takes place at all levels of education, but this process proceeds spontaneously, in "natural" conditions, including the conditions of the educational environment, we are faced with the question: "What are the lines of purposeful enrichment of the student's social interaction experience?”

The results of a theoretical analysis of the ideas and principles of the activity, environment, personality, anthropological approaches in the psychology of human education allowed us to distinguish three properties of the experience of social interaction that form the lines of its enrichment: subjectivity, co-existence, and reflexivity.

Mastering various types of activities increases the subjectivity of the personality, the functions of which are adaptive activity, self-determination and self-definition, settlement of contradictions, ensuring the productivity of activities, self-regulation, and self-governing. Subjectivity today is an essential characteristic of not only human, but also the most important property of social systems. In a changing world, the dominant socio-economic systems of the subjectivity have actively suppressed less developed systems. An increase in the subjectivity of society is impossible without an increase in the subjectivity of its members.

The subjectivity of the experience of social interaction is its enriched property (material). This line of enrichment is the progressive movement of its state from object experience (experience of object-subject interaction in the position of a controlled object) to subjective experience (subject-subject interaction) and then to polysubject experience (polysubject interaction).

Co-existence, according to E.I. Isaev and V.I. Slobodchikova, is an integrative characteristic of a person, manifested in "personal meanings, life values, energy of compatibility, revealed in joint activities" (Isaev \& Slobodchikov, 2013). Co-existence educational community is a source of formation of co-existence. These elements make up the essence of the core structures of the individual. This process requires overcoming the stereotypes existing in vocational education about the place and role of students in the educational process and the cultural and educational environment. A transition is necessary from the relatively passive position of the consumer of educational services to a self-organizing subject, transforming both the cultural and educational environment and itself.

When identifying the essential characteristics of the reflexivity of the experience of social interaction of a person, we proceed from the opinion of A.D. Leontiev and E.N. Osin, who understand reflection as "the ability of a person to arbitrarily turn consciousness to himself, ... which is the most important mechanism of self-knowledge and which gives a person an extra room" (Leontiev \& Osin, 2014).

\section{Conclusion}

The experience of social interaction is a mental trail of a person's practice in society and performs an orientation function in his life. Its structure consists of value-semantic, thought-activity and expressive-activity components. The experience of social interaction is formed in the hierarchical levels of the personality (the level of the core structures of the personality, the level of its relations with the world, the level of expressive-instrumental structures) and reflects the actively-active 
part of the social experience mastered by a person. Its content is the methods of worldview, intellectual and regulatory activity mastered by students in social situations.

Based on the study of the basic coordinates of the formation of the experience of social interaction (activity, consciousness, personality), three properties are determined that form the through directions (lines) of its enrichment for all levels of higher education: subjectivity, coexistence, and reflexivity.

The results of the study can serve as a theoretical basis for the design and implementation of pedagogical systems to enrich the experience of social interaction of students in the educational process at different levels.

\section{References}

Berger, P., \& Lukman, T. (1995). Social construction of reality. A treatise on the sociology of knowledge. Trans. by E. Rutkevich, M.: Academia-center, Medium, p. 334.

Comte, O. (1971). The course of positive philosophy. Anthology of world philosophy, 3, 584-586.

Dahrendorf, R. (1965). Elemente eines Theorie des sozialen Konflikts. Dahrendorf R. Gesellschaft und Freiheit, München.

Durkheim, E. (1996). On the division of social labor. - M.: Kanon, - 432 p.

Fromm, E. (2014). To have or to be? / Erich Fromm; trans. from English by E. Teliatnikova. Moscow: AST, $-320 \mathrm{p}$.

Hoffman, I. (2004). The analysis of frames: an essay on the organization of everyday experience. M.: Institute of Sociology RAS, - $752 \mathrm{p}$.

Homans, G.C. (1961). Social behavior: Its elementary forms. - N.Y.; Burlingame: Harcourt, Brace \& World Inc., - P. 1-16, 30-83, 378-398. // Social and human sciences / R.Zh. Ser. 11. Sociology. 2001. No. 2. P. 117-163 (beginning); No. 3. P. 132-169 (continued); No. 4. P. 98-122 (ending).

Isaev, E.I., \& Slobodchikov, V.I. (2013). Psychology of human education: The formation of subjectivity in educational processes. M., Publishing house of PSTSU, $432 \mathrm{p}$.

Istomina, S.V. (2015). Gender differences in value experience in adolescence. Concept, 12. URL: http://e-koncept.ru/2015/75187.htm (accessed date: 19.08.2019).

Kelly. (2000). Psychology of personality. Theory of personality constructs, St. Petersburg, Rech, $-256 \mathrm{p}$.

Kholodnaia, M.A. (2002). Psychology of intelligence: the paradoxes of research. - 2nd ed., revised. and ext. - St. Petersburg: Piter, 272 p.

Kovalenko, E.V. (2018). The experience of social interaction of a future specialist: theory and practice of formation. Monograph. Belgorod. Publisher: I.D. Putilin Belgorod Institute of Law, Ministry of Internal Affairs of Russia (Belgorod). - 184 p.

Kozer, L.A. (2000). The functions of social conflict (M.: Idea Press, House of Intellectual Books, $-205 \mathrm{p}$.

Leontiev, D. A. (1993). Essay on the psychology of personality. M., Smysl, 43 p.

Leontiev, D.A., \& Osin, E. N. (2014). Reflection of "good" and "bad": from an explanatory model to differential diagnosis. Psychology. Journal of the Higher School of Economics, 11(4): 110-135.

McLaren, P. (2007). Life in schools: an introduction to critical pedagogy. Trans. from English by O. Fadina. M.: Prosveshchenie, P. 265-311.

Mead, J. (1996). From gesture to symbol/ American Sociological Thought: Texts. M., P. 213-221.

Novikov, A.M. (2010). Foundations of pedagogy. M., Egves, 208 p.

Osnitskii, A.K. (2000). The structure, content, and functions of human regulatory experience. Author's abstract, Ph.D. Psychology. Moscow, - 370 p. 
Osnitsky, A.K., \& Korneeva, S.A. (2017). Neuropsychological phenomenology of self-regulation processes. Research result. Pedagogy and psychology of education, 3(4): 64-72. DOI: 10.18413/2313-8971-2017-3-4-64-72.

Parsons, T. (2018). Social system. - M.: Academic project, - 529 p.

Plotnikova, M.Iu. (2008). Enrichment of professional experience of students of psychologists as a prerequisite for the formation of professional self-awareness [Text]. Author's abstract, Ph.D. Psychology. M.Iu. Plotnikova. - Irkutsk, - 230 p.

Schütz, A. (2003). On the plurality of realities. Translated by Korbut A.M. Sociological review, 3(2): 3-34.

Sergeeva, E.A. (2011). Social interaction as the basis for building social reality: sociophilosophical analysis. Theory and practice of social development, 5, 36-41.

Simmel, G. (1996). Favorites. Volume 2. The Contemplation of Life - M.: Iurist, - 607 p.

Sorokin, P. (2008). System of sociology / Pitirim Alexandrovich Sorokin. - M.: Astrel, p. 1003

Weber, M. (1990). Basic sociological concepts: Trans. from Germ. Weber M. Selected works / M. Weber. M.: Progress, P. 603

Zimniaia, I.A. (2004). Key competencies as an effective and targeted basis of the competencybased approach in education. I.A. Zimniaia. - M.: Research Center for the Problems of Quality of Training of Specialists, - $38 \mathrm{p}$. 